\title{
Effect of Supplementation with Graded Levels of Concentrate Mix on Feed Intake, Digestibility, Body Weight Change, Carcass Parameters and Economic benefit of Arsi-bale Sheep Fed with Basal Diet of Urea Treated Barley Straw
}

\author{
Abebe Gemechu ${ }^{1^{*}}$ and Yoseph Mekasha ${ }^{2}$ \\ ${ }^{1}$ School of Animal and Range Sciences, Haramaya University, P.O. Box:138, Dire Dawa, Ethiopia \\ ${ }^{2}$ Department of Clinical Sciences, Swedish University of Agricultural Sciences (SLU), Uppsala, Sweden

\begin{tabular}{|c|c|}
\hline Abstract & Article Info \\
\hline \multirow{12}{*}{$\begin{array}{l}\text { The effects of supplementation with graded levels of concentrate mix on feed intake, live } \\
\text { weight gain, feed digestibility, carcass parameters and economic benefits of Arsi- Bale sheep } \\
\text { fed urea treated barley straw were evaluated in Tiyo Woreda, Arsi Zone. Twenty four yearling } \\
\text { male Arsi- Bale sheep with a mean ( } \pm \text { SD) initial live weight of } 18.72 \pm 0.87 \mathrm{~kg} \text { were purchased } \\
\text { from Asella livestock open market and assigned to one of the four treatments, Treatment } 1 \\
\text { (T1; Control) con stituted urea treated barley straw alone (UTBS), Treatment } 2 \text { (T2; UTBS } \\
+200 \mathrm{~g} \text { concentrate mixtures), Treatment } 3 \text { (T3; UTBS }+300 \mathrm{~g} \text { concentrate mixtures) and } \\
\text { Treatment } 4(\mathrm{~T} 4 \text {; UTBS + } 400 \mathrm{~g} \text { concentrate mixtures). Concentrate mix were prepared from } \\
\text { barley bran ( } 50 \% \text { ), linseed meal }(17 \%) \text { and malt barley by-product ( } 33 \%) \text {. Basal feed (urea } \\
\text { treated barley straw) dry matter intake was higher ( } p<0.001) \text { for sheep in the control } \\
\text { compared to supplemented group. Supplementation, in general, improved ( } p<0.05 \text { ) total dry } \\
\text { matter and nutrient intakes compared to the control. Among the supplemented group, sheep } \\
\text { in T4 has the highest total feed intakes and feed nutrients digestibility. Animals fed on the } \\
\text { control diet gained } 8.12 \text { g/d, while supplemented group gained weight in the range of } 48.82- \\
74.82 \text { g/d. Supplementation (T2-T4) improved ( } p<0.001 \text { ) slaughter body weight, empty body } \\
\text { weight and hot carcass weight as compared to the control (T1), particularly in T3 and T4 } \\
\text { better body weight gain, slaughter body weight, empty body weight and hot carcass weight } \\
\text { were recorded. Thus, it could be concluded that supplementing with T3 and T4 should be } \\
\text { better strategy to improve the performance of Arsi-Bale sheep. } \\
\text { Coopyright@2015 STAR Journal, Wollega University. All Rights Reserved. }\end{array}$} & rticle History: \\
\hline & Received : 12-07-2015 \\
\hline & evised \\
\hline & ted : 2 \\
\hline & \\
\hline & \\
\hline & ind nol \\
\hline & ep \\
\hline & tion \\
\hline & orresponding Author: \\
\hline & Gemechu \\
\hline & \\
\hline
\end{tabular}

\section{INTRODUCTION}

Livestock are integral components of the Ethiopian farming systems, and perform multiple functions at different levels of aggregation. At individual smallholder's level, livestock are important source of food (meat and milk), cash income, services (transport and traction) and manure (for soil fertility management and fuel). Livestock have also social and cultural values among producers, particularly for pastoralists.

Small ruminants are important protein sources in the diets of the poor and help to provide extra income and support survival for many farmers in the tropics and subtropics. Among the small ruminants, sheep contribute a substantial amount to the farm household income, mutton and non-food products (manure, skin and coarse wool). The short generation interval and ability to give multiple births make small ruminants production and management easy than other livestock under all levels of livelihood. They are a source of risk mitigation during crop failures, of property security and of monetary saving and investment in addition to many other socio-economic and cultural functions (Markos, 2006).

In Ethiopia, sheep are reared by smallholder farmer and graze with small flocks on communal open natural pastures in the highland agro-ecological setup (CSA, 2004). In pastoral form of production in lowland agroecological setup, sheep graze in large flocks (often mixed with other livestock) in communal grasslands. However, the communal grazing land in highland system is diminishing due to increments of crop production as a result of human population growth and increasing food demand. On the other hand, because of the increased crop production at the expense of pasture lands, the use of crop residues as animal feed resource is becoming important. However, crop residues have a very low feeding value with poor metabolizable energy (ME), low protein content and are seriously deficient in minerals and vitamins. The fact that crop residues are harvested after the plant is physiologically matured rendered it to have high cell wall and lignin and low protein contents. 


\section{Abebe Gemechu and Yoseph Mekasha}

Barley straw is among the dominant farm animal feeds in the highlands of Ethiopia particularly in barley-based farming, where crop and livestock production are well integrated. It is utilized as livestock feed as collected and used for stall feeding of livestock mostly during the dry season. Similar to the other crop residues, barley straw contains low protein and metabolizable energy supply deficient in vitamins and minerals but higher in fiber fraction. It has been documented that some sorts of processing or treatment of crop residues have positive effects on improving the nutritive value and eventually intake and digestibility of crop residues to a variable degree (Getahun, 2006). Alemayehu (2005) noted that urea treatment, chopping and mixing with high quality forages can improve the intakes and dietary quality of crop residues significantly. Urea treatment also reduces the fiber contents of low quality feed and supply nitrogen to rumen microbes that can be used to synthesis microbial protein.

In Arsi Zone where this study was conducted, crop residues such as barely straw, teff straw and wheat straw are utilized as livestock feed. Among these barley straw is dominant. Crop residues are utilized in two ways in this region. The residues are piled in stacks near homesteads and animals are let to eat from the stacks or given small quantities in the morning and evening, or before and after work for oxen without any treatment. Thus, it has been utilized less effectively since farmers are not aware of the technology. It has been shown that urea treatment improved feed intake, digestibility and growth performance of animal compared to untreated crop residues (Getahun, 2006).

In addition to various treatments supplementation of low quality feed resource with high nutrient feeds is another strategy followed to improve feed utilization and animal performance. Although, agro-industrial by products such as barley bran, wheat bran, linseed meals and malt barley by-product consist high nutrients and abundant in the study region, they have not been well utilized in the area. More specifically, malt barley by- product has not been used in the diet of small ruminants such as sheep. Since they are somewhat bitter in taste and contain high fiber it was not recommended to feed livestock excessively particularly for dairy and monogastric animals. Thus, it should be mixed with other feedstuffs to improve feed intake, reduce bitterness of the feed and its palatability. The current study was, therefore designed to e valuate the effects of supplementation with graded levels of concentrate mix on feed intake, body weight change, digestibility, carcass parameters and its economic benefits.

\section{MATERIALS AND METHODS}

\section{Study Site}

The study was conducted in Tiyo woreda at Berity, located at $25 \mathrm{~km}$ from Asella town in the Arsi Administration Zone of Oromiya National Regional State. Tiyo is located at $175 \mathrm{~km}$ southeast of Addis Ababa at $7^{\circ}$ $57^{\prime} \mathrm{N}$ Latitude $39^{\circ} 8$ ' E Longitude and at an altitudes of $2400 \mathrm{~m}$ above sea level. The study site receives bimodal type of rainfall with a mean annual precipitation of about $725 \mathrm{~mm}$ (KARC, 2009). The main rainy season extends from June to September with maximum rain fall in August, while the short rainy season is between February to April. The mean minimum and maximum temperature of the experimental site were 7.26 and $22.3{ }^{\circ} \mathrm{C}$, respectively
Sci. Technol. Arts Res. J., Oct-Dec 2015, 4(4): 01-08

(KARC, 2009). The woreda has a total area of $665 \mathrm{~km}^{2}$ of which 41.6, 13.7, 4.2, 14.9, 15.3 and $1.9 \%$ are covered with cultivated land, pastureland, forest land, bush and shrubs used for construction and mountains, respectively. From the cultivated land, 82.9, 15.3 and $1.9 \%$ is covered with cereals, pulses and oil crops, respectively (AZARDO, 2009).

\section{Managements of Experimental Animals}

A total of twenty four intact male yearling Arsi-Bale sheep with initial body weight of $18.72 \pm 0.87 \mathrm{~kg}$ (mean \pm $\mathrm{SD}$ ) were purchased from Asella open market. The age of sheep was estimated by dentition of first drop and purchasing price of sheep was recorded for each sheep during the purchasing time. The experimental sheep were quarantined for three weeks. During this period, experimental sheep were vaccinated against infectious diseases such as black leg, pasteurellosis, actinomycosis and sheep pox, which are commonly found in the study area; and treated against parasitis diseases such as fasciollosis (Fasinex) and Dicticulosis (Tetraclazon). Upon completion of quarantine period, animals were adapted to experimental feeds for 15 days. During this period animals penned and fed individually in $1 \times 1 \times 0.8$ height $\left(\mathrm{m}^{3}\right)$ pen. The pens were cleaned every morning before feed offer to the sheep. All animals were offered the supplement feed in two equal portions at 0800 and 1600 hr. Water was also provided twice per day at similar time.

\section{Feed Preparation and Feeding}

The basal diet used for the experiment was urea treated barley straw. The untreated straw was purchased from farmers in the study area. Two equal sized pits were prepared for straw ensiling purpose. The volume of the pit was determined by assuming estimated total straw consumption during the feeding period. The pits were well prepared and covered with plastic sheet to prevent from soil contact or spoilages of straw. Before ensiling the straw urea solution was prepared as $5 \mathrm{~kg}$ urea dissolved in 100 liters of water and mixed with $100 \mathrm{~kg}$ of straw. The straw was immersed with urea solution by rubbing and uniformly spraying on all surface of the straw. The mixtures were placed into the pit, trampled and made compact until it fills to the pit capacity. The straw was stored properly by sealing the top of the pit and loaded to make it airtight. It was left unopened for 21 days. At the end of the treatment period of 21 days, the pit was opened and ventilated for $24 \mathrm{hr}$. Urea treated barley straw had dark yellow color, ammonia smell and softer than untreated one. Portion of straw was taken daily and offered to the experimental animals at $25 \%$ refusal.

Supplement feeds were consisted of barley bran (BB) (haulm of barley grain after milling for human food purpose), malt barley by-products (MBP) (culm or sprout of malted barley grain prepared for brewery in malt factory) and linseed meal (LSM) (cake or meal obtained after extraction of oil from flax seed that mixed at a ratio of 50,33 and $17 \%(3: 2: 1)$ for BB, MBP and LSM, respectively. The ration was formulated to provide $16 \%$ $\mathrm{CP}$ and $7.4 \mathrm{MJ} / \mathrm{kg}$ DM energy to ensure at least $50 \mathrm{~g} / \mathrm{d}$ of average daily gain of sheep (McDonald et al., 2002).

\section{Experimental Design and Treatment}

A randomized complete block design (RCBD) with four treatments, each replicated six times was used for this experiment. The animals were blocked into six blocks based on their initial body weight. The four treatments were randomly assigned to animals within a block. 
Table 1: Experimental treatment

\begin{tabular}{cccc}
\hline Treatment & $\begin{array}{c}\text { Urea Treated } \\
\text { Barley Straw }\end{array}$ & $\begin{array}{c}\text { Supplements (ratio) } \\
\text { LM:MBP:BB }\end{array}$ & $\begin{array}{c}\text { Total Supplements }(\mathbf{g}) \\
\text { DM/h/d }\end{array}$ \\
\hline Treatment 1 & Ad libitum & $0: 0: 0$ & 0 \\
Treatment 2 & Ad libitum & $3: 2: 1$ & 200 \\
Treatment 3 & Ad libitum & $3: 2: 1$ & 300 \\
Treatment 4 & Ad libitum & $3: 2: 1$ & 400 \\
\hline Supplement: Mixture of barley bran (50\%), malt barley by- product (33\%) and linseed meal (17\%).
\end{tabular}

\section{Feeding Trial}

After the adaptation period the actual experiment was run for 90 days. The daily feed offer and refusal were weighted and recorded for each sheep and daily feed intake was calculated as difference between the feed offered and refused. Samples were taken from the basal (urea treated barley straw) and supplement feed for chemical analysis. Similarly the refusals were weighted and sampled per each animal, pooled on treatment basis over the feeding period.

\section{Body Weight Change}

The initial body weight of experimental sheep was taken before the start of the experiment and then measured at every ten days interval after over night fasting by using hanging weighing scale. At the end of experiment, final body weight was measured. Average daily gain was calculated as the difference between final and initial body weight divided by the number of experimental days. Feed conversion efficiency (FCE) was determined by dividing body weight gain by total dry matter intake

\section{Digestibility Trail}

At the end of feeding trial, experimental animals were fitted with the fecal collecting bags and the animals were given three days to adapt to the bags. During digestion trial, feed offered and refusal was measured separately for basal diet and supplements. Feces were collected for 7 consecutive days. Collected feces were weighed, recorded and $20 \%$ were sampled and stored in deep freeze at $-20 \mathrm{C}$. At the end of the digestibility trial, feces were pooled per animal, thoroughly mixed for each animal and composite sample was taken for chemical analysis. The composite feces were weighed and dried in oven at $60^{\circ} \mathrm{C}$ for 72 hour to constant weight at the Department of Animal Science laboratory, Adama University, Asella School of Agricultural Campus. The dried fecal samples were ground to pass through $1 \mathrm{~mm}$ sieve for chemical analysis. The apparent digestibility coefficient (DC) was calculated by using the following equation:

\section{$D C=\underline{\text { Nutrient intake-Nutrient excreted in feces }} \times 100$ Nutrient intake}

\section{Carcass Evaluation}

Carcass parameters were measured at the end of the digestibility trials. All sheep from each treatment were fasted overnight, weighed and slaughtered. During slaughtering, blood was collected in a container and weighed. Weight of edible offal component like heart, liver, kidney, tongue, tail, large and small intestine were weight and recorded. Empty body weight of each animal was determined by subtracting the gut content from the slaughter weight. Dressing percentage was calculated as a proportion of hot carcass weight to slaughter and empty body weights. Hot carcass weight was computed by excluding, head, skin, and feet (cut off at the proximal end of canon bone). The rib-eye muscle area of each animals were determined by tracing the cross sectional area of the $11^{\text {th }}$ and $12^{\text {th }}$ ribs after cutting perpendicular to the backbone and measured by planimeter. The mean of the right and left cross-sectional areas was taken as a rib-eye muscle area.

\section{Chemical Analysis}

Chemical analysis was done for feeds, refusal and feces samples. The samples were dried in an oven at $105^{\circ} \mathrm{C}$ over night in a forced draft oven at Haramaya University Animal Nutrition Laboratory to determine the DM of the feed and feces. The dried samples of feeds and feces were ground to pass through $1 \mathrm{~mm}$ screen size. Neutral Detergent Fiber (NDF), Acid Detergent Fiber (ADF) and Acid Detergent Lignin (ADL) were determined following the procedures of Van Soest and Roberson (1985). The OM, Ash and Nitrogen (N) were analyzed according to the procedures of AOAC (1990). Crude protein $(\mathrm{CP})$ was calculated as $\mathrm{N} \times 6.25$. The $\mathrm{OM}$ was calculated as 100- Ash.

\section{Statistical Analysis}

Data on feed intake, body weight change, digestibility of experimental feeds and carcass parameters were subjected to the analysis of variance using General Linear Model Procedures of SAS (2002). Treatment means were separated using Least Significant Difference test. The following model was used for the analysis.

$$
Y i j=\mu+t i+b j+e i j
$$

Where:

Yij= observation in the $j^{\text {th }}$ block and $i^{\text {th }}$ treatment

$\mu=$ the overall mean

$\mathrm{t} i=$ the $\mathrm{i}^{\text {th }}$ treatment effect

$\mathrm{bj}=$ the $\mathrm{jth}$ block effect

eij= the random error

\section{RESULTS}

The chemical composition of feedstuff (Table 2), digestibility of experimental feed (Table 3 ), body weight change (Table 4), the trends in body weight changes over the feeding days (Figure 1), Carcass parameters (Table 5 ), Edible offal components (Table 6), Non-edible offal components (Table 7) were determined and represented for Arsi-bale sheep fed with basal diet of urea treated barley straw. 
Table 2: Chemical composition of experimental feeds

\begin{tabular}{|c|c|c|c|c|c|}
\hline \multirow{2}{*}{ Variables } & \multicolumn{2}{|c|}{ Barley straw } & \multirow{2}{*}{ BB } & \multirow{2}{*}{ LSM } & \multirow{2}{*}{ MBP } \\
\hline & Untreated & Urea treated & & & \\
\hline DM \% & 93.7 & 91.2 & 90.5 & 91.16 & 91.3 \\
\hline OM (\% DM) & 88.9 & 90.9 & 95.08 & 92.83 & 95.72 \\
\hline $\mathrm{CP}(\% \mathrm{DM})$ & 4.80 & 9.45 & 10.32 & 24.56 & 22.81 \\
\hline NDF ( $\%$ DM) & 84.61 & 66.16 & 68.9 & 38.57 & 52.03 \\
\hline ADF (\% DM) & 66.15 & 55.38 & 15.7 & 20.9 & 21.23 \\
\hline ADL (\% DM) & 3.68 & 8.77 & 4.07 & 8.67 & 7.0 \\
\hline $\mathrm{ASH}(\% \mathrm{DM})$ & 11.1 & 9.06 & 4.92 & 7.17 & 4.28 \\
\hline
\end{tabular}

$\mathrm{DM}=$ dry matter, $\mathrm{BB}=$ barley bran, $\mathrm{LSM}=$ linseed meal and $\mathrm{MBP}=$ malt barley by- product, $\mathrm{OM}=$ organic matter,

$\mathrm{CP}=$ crude protein, $\mathrm{NDF}=$ neutral detergent fiber, $\mathrm{ADF}=$ acid detergent, $\mathrm{ADL}=$ acid detergent fiber.

Table 3: Nutrient digestibility in Arsi-Bale sheep fed urea treated barley straw and supplemented with graded level of concentrate mix

\begin{tabular}{clllll}
\hline & \multicolumn{4}{c}{ Digestibility Coefficient } & \multirow{2}{*}{ SEM } \\
\cline { 2 - 5 } & \multicolumn{1}{c}{ T1 } & \multicolumn{1}{c}{ T2 } & \multicolumn{1}{c}{ T3 } & \multicolumn{1}{c}{ T4 } & \\
\hline DMD (g) & $0.612^{\mathrm{d}}$ & $0.696^{\mathrm{c}}$ & $0.743^{\mathrm{b}}$ & $0.773^{\mathrm{a}}$ & 0.015 \\
OMD (g) & $0.623^{\mathrm{d}}$ & $0.676^{\mathrm{c}}$ & $0.75^{\mathrm{b}}$ & $0.780^{\mathrm{a}}$ & 0.04 \\
CPD (g) & $0.68 .1^{\mathrm{b}}$ & $0.707^{\mathrm{ab}}$ & $0.773^{\mathrm{a}}$ & $0.817^{\mathrm{a}}$ & 0.015 \\
NDFD (g) & $0.650^{\mathrm{b}}$ & $0.662^{\mathrm{b}}$ & $0.688^{\mathrm{a}}$ & $0.710^{\mathrm{a}}$ & 0.018 \\
ADFD (g) & $0.413^{\mathrm{d}}$ & $0.510^{\mathrm{c}}$ & $0.555^{\mathrm{b}}$ & $0.619^{\mathrm{a}}$ & 0.033 \\
\hline
\end{tabular}

${ }^{\mathrm{a}-\mathrm{d}}$ Means within a row not bearing similar supper script letters are significantly differ. $\mathrm{DM} \mathrm{D}=\mathrm{dry}$ matter digestibility,

$\mathrm{OM} D=$ organic matter digestibility, $\mathrm{CPD}=$ crude protein digestibility, NDFD = neutral detergent fiber digestibility, $A D F D=$ acid detergent fiber digestibility, $L S=$ list significant, $S E M=$ standard error means,

T1=UTBS (urea treated barley straw), T2 = UTBS +200 g mix, T3 = UTBS +300 g mix, T4 = UTBS +400 g mix

Table 4: Average body weight change of Arsi-Bale sheep fed urea treated barley straw and supplemented with graded levels of concentrate mix

\begin{tabular}{cccccc}
\hline \multirow{2}{*}{ Parameters } & \multicolumn{4}{c}{ Treatments } & \multirow{2}{*}{ SEM } \\
\cline { 2 - 5 } & T1 & T2 & T3 & T4 & \\
\hline Initial weight $(\mathrm{kg})$ & 18.48 & 18.62 & 18.88 & 18.72 & 0.21 \\
Final weight $(\mathrm{kg})^{19.22^{\mathrm{d}}}$ & $23.00^{\mathrm{C}}$ & $24.35^{\mathrm{b}}$ & $25.45^{\mathrm{a}}$ & 0.52 \\
ADG (g/d) & $8.22^{\mathrm{C}}$ & $48.70^{\mathrm{b}}$ & $60.72^{\mathrm{a}}$ & $74.82^{\mathrm{a}}$ & 0.57 \\
FCE & $2.04^{\mathrm{c}}$ & $6.81^{\mathrm{b}}$ & $7.01^{\mathrm{a}}$ & $8.53^{\mathrm{a}}$ & 5.59
\end{tabular}

${ }^{\mathrm{a}-\mathrm{b}}$ Means within a row not bearing similar superscript letters are significantly different,.

$A D G=$ average daily gain, $\mathrm{FCE}=$ feed conversion efficiency, $\mathrm{SEM}=$ standard error of mean,

T1=UTBS (urea treated barley straw), T2 = UTBS $+200 \mathrm{gmix}, \mathrm{T} 3=$ UTBS $+300 \mathrm{~g} \mathrm{mix}, \mathrm{T} 4=$ UTBS $+400 \mathrm{~g}$ mix

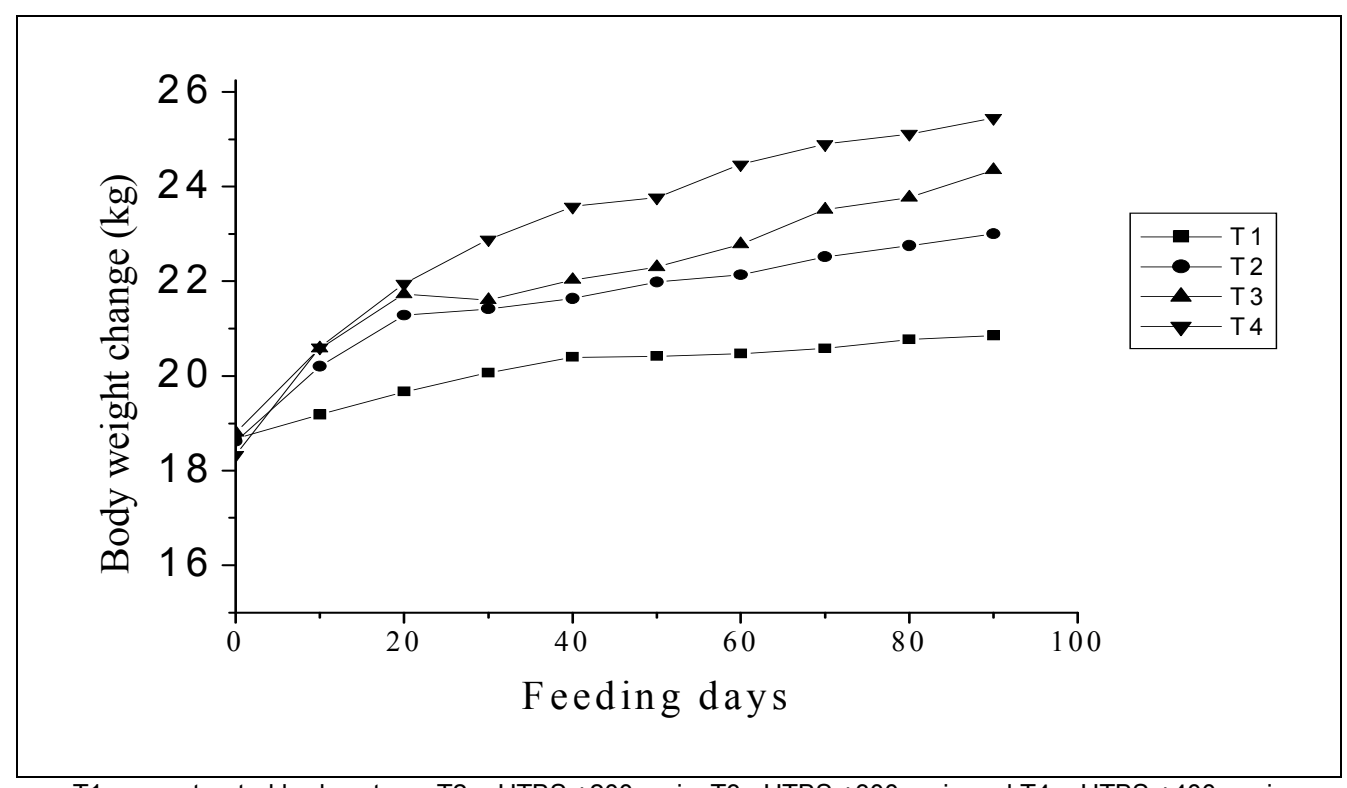

T1 = urea treated barley straw, T2 = UTBS +200g mix, T3= UTBS +300g mix and T4 = UTBS +400 g mix

Figure 1: The trends in body weight changes over the feeding days of Arsi-Bale sheep fed a basal diet of urea treated barley straw and supplemented with graded levels of concentrate mix 
Table 5: Carcass parameters of Arsi-Bale sheep fed urea treated barley straw and supplemented with graded levels of concentrate mix

\begin{tabular}{|c|c|c|c|c|c|}
\hline \multirow[b]{2}{*}{ Parameters } & \multicolumn{4}{|c|}{ Treatments } & \multirow[t]{2}{*}{ SEM } \\
\hline & $T_{1}$ & $T_{2}$ & $T_{3}$ & $T_{4}$ & \\
\hline Slaughter BW (Kg) & $19.00^{C}$ & $22.7^{\mathrm{b}}$ & $24.2^{b}$ & $25.4^{\mathrm{a}}$ & 0.5 \\
\hline Empty BW (kg) & $13.9^{\mathrm{C}}$ & $18.5^{\mathrm{b}}$ & $19^{\mathrm{a}}$ & $20.5^{a}$ & 0.7 \\
\hline Hot carcass weight $(\mathrm{kg})$ & $5.6^{\mathrm{c}}$ & $8^{\mathrm{b}}$ & $8.9^{a}$ & $9.6^{a}$ & 0.4 \\
\hline \multicolumn{6}{|l|}{ Dressing percentage (\%) } \\
\hline Slaughter BW base & $29.5^{c}$ & $35.2^{\mathrm{b}}$ & $36.8^{\mathrm{a}}$ & $38.2^{\mathrm{a}}$ & 1.17 \\
\hline Empty BW base & $40.2^{\mathrm{b}}$ & $43.2^{\mathrm{b}}$ & $46.8^{a}$ & $47.00^{a}$ & 1.12 \\
\hline
\end{tabular}

${ }^{\mathrm{a}-\mathrm{d}}$ Means within a row not bearing similar superscript are significantly different, BW = body weight; SEM = standard error of means; $\mathrm{T}_{1}($ control $)=$ urea treated barley straw $\left(\right.$ UTBS) alone; $\mathrm{T}_{2}=\mathrm{UTBS}+200 \mathrm{~g} / \mathrm{head} / \mathrm{d} \mathrm{mix} ; \mathrm{T}_{3}=\mathrm{UTBS}+300 \mathrm{~g} / \mathrm{head} / \mathrm{d} \mathrm{mix} ; \mathrm{T}_{4}=\mathrm{UTBS}+400$ $\mathrm{g} / \mathrm{head} / \mathrm{d}$ mix of BB=barley bran, Lsm=linseed meal and MBP = malt barley by-products

Table 6: Edible offal Components of Arsi-Bale sheep fed urea treated barley straw and supplemented with graded levels of concentrate mix

\begin{tabular}{|c|c|c|c|c|c|}
\hline \multirow{2}{*}{ Parameters } & \multicolumn{4}{|c|}{ Treatments } & \multirow[t]{2}{*}{ SEM } \\
\hline & $T_{1}$ & $\mathbf{T}_{2}$ & $T_{3}$ & $T_{4}$ & \\
\hline Blood (g) & $715.7^{c}$ & $1245.2^{b}$ & $1224.5^{b}$ & $1331.8^{\mathrm{a}}$ & 52.1 \\
\hline Heart (g) & $81^{\mathrm{C}}$ & $93^{b}$ & $103.1^{\mathrm{ab}}$ & $100.2^{\mathrm{a}}$ & 2.2 \\
\hline Liver (g) & $308.3^{d}$ & $341.9^{c}$ & $378.4^{\mathrm{b}}$ & $424.3^{\mathrm{a}}$ & 11.7 \\
\hline Kidneys (g) & $57.7^{\mathrm{c}}$ & $74.4^{\mathrm{b}}$ & $88.7^{\mathrm{a}}$ & $87.5^{\mathrm{a}}$ & 2.8 \\
\hline Kidneys fat (g) & $33.2^{d}$ & $41.5^{\mathrm{c}}$ & $45.9^{b}$ & $54.9^{\mathrm{a}}$ & 1.8 \\
\hline Testis (g & $110.3^{b}$ & $219.5^{\mathrm{a}}$ & $215.9^{a}$ & $211.5^{\mathrm{a}}$ & 9.9 \\
\hline Tongues (g) & $60.9^{b}$ & $72.4^{\mathrm{a}}$ & $71.2^{\mathrm{a}}$ & $72.6^{a}$ & 1.4 \\
\hline Empty gut (g) & $1298.2^{b}$ & $1698.8^{\mathrm{a}}$ & $1699.3^{a}$ & $1748.2^{\mathrm{a}}$ & 39.2 \\
\hline Omentaland mesenteric & $66.6^{d}$ & $142.7^{\mathrm{C}}$ & $155.5^{\mathrm{b}}$ & $175.5^{\mathrm{a}}$ & 8.7 \\
\hline Tail $(g)$ & $611.7^{\mathrm{C}}$ & $1014.5^{\mathrm{a}}$ & $1014.5^{\mathrm{a}}$ & $1016.2^{\mathrm{a}}$ & 66.4 \\
\hline Genital fat $(\mathrm{g})$ & $19.2^{\mathrm{C}}$ & $90.8^{b}$ & $94.6^{b}$ & $134.2^{\mathrm{a}}$ & 8.8 \\
\hline Omasum and abomasums (g) & $196.7^{d}$ & $213.9^{c}$ & $226.5^{\mathrm{b}}$ & $235.1^{\mathrm{a}}$ & 8.7 \\
\hline Large and small intestines $(\mathrm{g})$ & $551.5^{\mathrm{d}}$ & $917.2^{\mathrm{C}}$ & $961.1^{\mathrm{b}}$ & $982.2^{\mathrm{a}}$ & 36.7 \\
\hline Reticulo-Rumen (g) & $461.9^{d}$ & $533.9^{\mathrm{C}}$ & $558.9^{b}$ & $589.1^{\mathrm{a}}$ & 10.01 \\
\hline TEOC $(\mathrm{kg})$ & $4.7^{\mathrm{d}}$ & $6.9^{\mathrm{C}}$ & $7.2^{\mathrm{b}}$ & $6.5^{\mathrm{a}}$ & 0.24 \\
\hline
\end{tabular}

${ }^{a-d}$ Means within a row not bearing similar superscript letters are significantly different;

$\mathrm{SL}=$ significant level; SEM= standard error of means; $\mathrm{TMCC}=$ total main carcass components;

$\mathrm{T}_{1}$ (control) =urea treated barley straw (UTBS); $\mathrm{T}_{2}=\mathrm{UTBS}+200 \mathrm{~g} ; \mathrm{T}_{3}=\mathrm{UTBS}+300 \mathrm{~g}$ and $\mathrm{T}_{4}=\mathrm{UTBS}+400 \mathrm{~g}$

Table 7: Non-edible offal components of Arsi-Bale sheep fed urea treated barley straw and supplemented with graded level of concentrate mix

\begin{tabular}{|c|c|c|c|c|c|}
\hline \multirow{2}{*}{ Parameters } & \multicolumn{4}{|c|}{ Treatments } & \multirow{2}{*}{ SEM } \\
\hline & T1 & T2 & T3 & T4 & \\
\hline Skin and feet & $1408.3^{c}$ & $1407.8^{b}$ & $2088.7^{\mathrm{ab}}$ & $2300^{\mathrm{a}}$ & 73.7 \\
\hline Head without tongue $(\mathrm{g})$ & $1015.6^{c}$ & $1370.5^{\mathrm{b}}$ & $1387.1^{b}$ & $1465.7^{\mathrm{a}}$ & 37.2 \\
\hline Penis $(g)$ & $44.1^{\mathrm{c}}$ & $54.7^{\mathrm{ab}}$ & $58.4^{\mathrm{ab}}$ & $62.4 a$ & 0.77 \\
\hline Testicles (g) & $176.5^{\mathrm{d}}$ & $298.9^{\text {bc }}$ & $363.1^{\mathrm{c}}$ & $378^{a}$ & 16.6 \\
\hline Lung, esophagus and trachea $(\mathrm{g})$ & $208.9^{C}$ & $455^{\mathrm{ab}}$ & $469.8^{\mathrm{ab}}$ & $479^{a}$ & 23.7 \\
\hline Spleen $(\mathrm{g})$ & $40.4^{c}$ & $58.4^{\mathrm{b}}$ & $56.9^{\mathrm{ab}}$ & $62.4^{\mathrm{a}}$ & 23.6 \\
\hline Gall bladder with bile $(\mathrm{g})$ & $2.8^{\mathrm{C}}$ & $17.3^{\mathrm{b}}$ & $20.3^{a}$ & $19.3^{\mathrm{a}}$ & 1.49 \\
\hline TNEOC (kg) & $2.5^{\mathrm{d}}$ & $3.3^{\mathrm{c}}$ & $4.0^{b}$ & $4.4^{\mathrm{a}}$ & 0.2 \\
\hline
\end{tabular}

\section{DISCUSSION}

\section{Chemical Composition of Feedstuff}

The DM content of urea treated barley straw (UTBS) used in this trial was greater than $69 \%$ reported by Getahun (2006) but lower than $92.5 \%$ reported by Awet (2007). The DM content of urea treated barley straw was lower than that of untreated barley straw in this study. This might be due to addition of water during urea treatment and water from the pit during fermentation reaction of the mixed straw. Similarly, the OM content of urea treated straw was lower than that of untreated straw. However, the OM content $(90.6 \%)$ of urea treated basal diet is comparable with $90.4 \%$ reported by Getahun (2006). The DM content of barley bran (BB) is relatively lower than malt barley by-product (MBP); however, the value for linseed meal is between the two. 


\section{Abebe Gemechu and Yoseph Mekasha}

In the current study the NDF and ADF contents of urea treated barley straw were significantly lower compared to the untreated straw. Contrary to this the ADL content of UTBS increased from 3.68 to $8.77 \%$. This implies that hemicelluloses portion of cell wall components of barley straw was readily affected with urea treatment. These results agree with the decreased NDF and ADF content of urea treated wheat straw from 80.7 to $74.3 \%$ and from 52.3 to $50.4 \%$, respectively (Getahun, 2006). However, NDF and ADL values in the present study were lower than 83.1\% NDF and $11.6 \%$ ADL reported by Dawit (2007). The same author explained that the removal of soluble components of NDF, such as nitrogen free extract (NFE), ether extract and soluble carbohydrate results in the increase of ADF and ADL values. The NDF content of barley bran in the present study was higher than NDF content of wheat bran (44.94\%) and of barley bran $42.3 \%$ as reported by Abebe (2006) and Ermias (2008), respectively.

The result demonstrated that urea treatment of barley straw improved the CP content by $96.9 \%$. This might be due to nitrogen supplied from urea solution during treatment of barley straw. The result is an agreement with that reported by Dawit (2007) who found that CP content of barley straw treated with urea solution improved by $91.8 \%$. However, improvement in CP content in the present study is higher and CP content of barley bran used in present study is comparable with values of $9.7 \%$ reported by Ermias (2008). The current CP value for malt barley by-product is lower than $25.9 \%$ CP reported by Birhanu (2010). Similarly, Harris et al. (2003) reported that the CP value of malt barley by-product is greater than 24 $\%$. Linseed meal is the main source of protein which accounted for $24.56 \% \mathrm{CP}$ that was comparable with $24.8 \%$ CP reported by Ermias (2008), but lower than 26.7 $\%$, reported by Abebe (2006).

\section{Digestibility of Experimental Feed}

Dry matter (DM,) OM, NDF and ADF digestibilities were significantly higher $(p<0.001)$ for supplemented groups compared to the control $\left(T_{1}\right)$. The difference in digestibility of nutrients might be attributed to difference in nutrient supply. Although digestibility of the currently used basal diet was lower than the supplement feed, it has shown high improvement. FAO (2002) reported 20\% improvements in digestibility due to ammoniation of poor quality roughages. The DM digestibility coefficient of urea treated barley straw in the present study is higher than the 0.45 reported for the same feed (Dawit, 2006). This might be due to the relatively higher $\mathrm{CP}$ and medium fiber contents of urea treated straw in the current study. T4 diet had higher $(p<0.001)$ digestibilities of DM, OM, NDF and ADF compared to the diets in T2 and T1. This might be due to sufficient supply of protein and energy to rumen microbes by the respective feeds. The finding is in agreement with Jemberu (2008) who reported that sheep supplemented with high levels of concentrate mix had significantly higher $(i<0.01)$ DM digestibility than the control. The current result is comparable with Misra et al. (2006) and Hirut (2008) who reported DM digestibility of 0.56 and 0.54 for UTMS and wheat straw, respectively.

The NDF digestibility coefficient was higher in T4 than the T2 and T1 treatments. This is probably due to the supply of protein from linseed meal and malt barley byproduct that made NDF part of the diet readily digested by rumen microbes. Similarly, the digestibility coefficient of
Sci. Technol. Arts Res. J., Oct-Dec 2015, 4(4): 01-08

NDF in the current experiment across all the treatments was higher than 0.62 and 0.56 reported for linseed meal and barley bran mixture at different proportions (Ermias, 2008). Significant difference was also observed between $\mathrm{T}_{3}$ and $\mathrm{T}_{4}$ in ADF digestibility

The lower digestibility of CP in sheep fed only urea treated barley straw compared to all the supplemented diet might be related to the lower CP content of the basal diet. Generally, concentrate feed which is rich in protein content promotes high microbial population that facilitates rumen fermentation (McDonald et al., 2002). The increased digestibility of $\mathrm{CP}$ in supplemented animals compared to un-supplemented ones could be due to higher supply of dietary $\mathrm{CP}$ in the diet. However, there was no significant difference $(p>0.05)$ between $T_{3}$ and $T_{4}$ in CP digestibility. This might be due to similarity in nutrients provided by the two treatments. In supplemented treatment, the digestibility of all nutrients showed increment with increasing levels of concentrate mix. Enhancement of the nutrient digestibility might be connected with increment of nutrient at high levels. The moderate digestibility of nutrients observed at lower level of supplementation in this experiment might be related to the nutrient content and digestibility of the respective ingredients.

\section{Body Weight Change}

The study demonstrated that treatment diets (T2-T4) improved $(p<0.001)$ daily BW gains compared to sheep in the control diet (T1). Among supplemented sheep there were significant difference $(p<0.05)$ in mean daily body weight gain. This might be due to differences in muscle development in sheep due to varied levels of supplementation. However, there was no significant difference $(p>0.05)$ among $T_{2}$ and $T_{3}$ in daily BW gain.

Experimental sheep supplemented with concentrate feeds having different CP content had higher $(p<0.001)$ daily live weight gains as compared to sheep on the control diet. However, sheep in the control treatment maintained their live weight with slight gains $(8.2 \mathrm{~g} / \mathrm{d})$, which agrees with the finding of Getahun (2006) who indicated that sheep offered sole urea treated wheat straw gained $10.7 \mathrm{~g} / \mathrm{d}$. However, contrary to the current study, sheep offered urea treated maize Stover lost $14.4 \mathrm{~g}$ per day (Hirut, 2008; Melese, 2008). This variation might be due to difference in roughage used, environmental condition under which the experiment was conducted and method of treatment. In fact urea treated roughage provide nitrogen which helps the animal to maintain their protein needs and provides conducive environments to rumen microbes to conduct their activity such as nutrient digestibility and protein synthesis properly. In such situation treating of locally available roughage with urea for livestock feed is beneficial to farmers with low income group than using highly expensive agro-industrial byproducts.

Sheep in T3 and T4 had better performance $(p<0.001)$ in body weight change than animals in T2. This might be due to higher protein in treatments (T3 and T4. The trend in body weight change of sheep supplemented with T4 and T3 showed uniform sharp increment during the first 20 days of the feeding period, while sheep in the control treatment maintained the lowest (Figure 1). However, there is a clear discrepancy between T4 and T3 after 20 days of the feeding period where sheep in the former 
Abebe Gemechu and Yoseph Mekasha

treatment were superior in body weight change throughout the experiment. This demonstrates that supplementation of sheep with higher nutrients is essential to maximize production and exploit the genetic potential of the animals.

The feed conversion efficiency (FCE) was significantly higher $(p<0.001)$ for the supplemented treatments compared to the control. The higher feed conversion efficiency was recorded for T4 and T3 as compared to the other treatments and this could be due to the higher content of energy and protein in this treatment. The FCE trend observed among the animals indicated that as the proportion of total DM intake consumed increased, the FCE also improved.

\section{Carcass Evaluation}

\section{Carcass Parameters}

Slaughter and empty body weight, and hot carcass weight were higher for supplemented sheep compared to sheep in the control. However, there was no significant $(p>0.05)$ difference among $T_{3}$ and $T_{4}$ in their empty and hot carcass weights and rib-eye muscle area. Biru (2008) and Emebet (2008) also indicated that supplementation had positive effect on hot carcass weight, empty body weight and dressing percentage on slaughter weight and empty body weight basis. This could be due to the higher nutrients provided by the supplements.

Rib-eye muscles area was significantly different $(p<0.001)$ between supplemented and control groups. The higher rib eye muscle area was observed in $\mathrm{T}_{4}$ compared to $T_{2}$. It has been reported that rib eye muscle area increases with increased levels of concentrate supplementation (Amare, 2007). This indicates that high level of supplementation would enable sheep to develop better muscling than the control and lower level of supplemented sheep

\section{Non Carcass Parameters (Offals) Edible Offal Components}

The proportion of blood to slaughter BW were 3.6\%, $5.5 \%, 5.1 \%, 5.3 \%$ for control $\left(\mathrm{T}_{1}\right), \mathrm{T}_{2}, \mathrm{~T}_{3}$, and, $\mathrm{T}_{4}$, respectively. The current result showed higher $(P<0.001)$ weight in edibles offal components than the result reported by Ermias (2008). This may be due to the contribution of malt barley by-product and nitrogen provided from urea treated barley straw for development of edible offal components. The control treatment had lower $(p<0.001)$ kidney, omental, heart and genital fat as compared to the supplemented treatment group. In agreement with the present result, sheep fed faba bean haulm and supplemented with barley bran and linseed meal mixture gained heavier weight of visceral fat than sheep fed the control treatment (Ermias, 2008). There was no significant difference $(p>0.05)$ among supplemented group in empty gut and tongue weights but highly significant difference $(p<0.001)$ were observed in large intestine, reticulo-rumen, omasum and abomasums between supplemented groups.

\section{Non-edible Offal Components}

Skin and feet weights of the control treatment was lower $(p<0.001)$ than the supplemented treatments. For the same parameters, there were no significant differences $(p>0.01)$ observed among $T_{3}$ and $T_{4}$. Head without tongue, testicles, lung and diaphragm, spleen, bladder and total non-edible offal components (TNEOC)

\section{Sci. Technol. Arts Res. J., Oct-Dec 2015, 4(4): 01-08}

of the control treatment were lower $(p<0.001)$ than the supplemented treatment. Contrary to this, Awet and Solomon (2009), Tesfaye and Solomon (2009) and Hirut (2008) reported no significance difference in TNEOC weight between sheep in supplemented and control treatments.

The current study also revealed that mixing of different concentrate feed, which have different protein and energy contents of malt barley by-product, linseed meal and barley bran is increase in weight of non-edible offal components than MBP alone and their mixture with wheat bran in non-edible offal components weight. Thus, linseed meal and urea treated barley straw play a greater role in increments of non-edible offal components

\section{CONCLUSIONS}

This studies result revealed that supplementation of Arsi-Bale sheep fed abasal diet of urea treated barley straw with $300 \mathrm{~g}$ (T3) and $400 \mathrm{~g}$ (T4) concentrate mix improved average daily body weight gain, slaughter body weight, hot carcass and empty body weight of the expermental sheep. Thus, it could be concluded supplementation of Arsi-Bale sheep with T3 and T4 and using urea treated barley straw base feeding system can improve performance of sheep.

\section{Conflict of Interest}

Conflict of interest none declared.

\section{Acknowledgements}

First and foremost, special thanks and heart-felt appreciation go to my major and co- advisors Dr.Yoseph Mekasha and Dr. Mengistu Urge, respectively for their unresearved support and guidance during my research work. I sincerely acknowledge the Ministry of Education (MOE) for giving me an opportunity to pursue post graduate study and for the smooth and fast financial release for the research work.

\section{REFERENCES}

Abebe Tafa. (2007). Supplementation with linseed cake, wheat bran and their mixture on feed intake, digestibility, and live weight change and carcass parameters in intact male Arsi-Bale sheep. An MSc Thesis presented to school of graduate studies of Haramaya University. pp.19-37.

Alemayehu Mengistu (2005). Short communication in grass land development option. Ethiopian Journal of Animal Production 5 (2):125-131.

Amare Dessie (2007). Effect of Supplementation of CactusTeff straw based diets with oil seed cake o feed utilization. Body weight change and carcass traits of Tigray Highland sheep.

AOAC (1990). Methods of Analysis, $15^{\text {th }}$ ed., Association of official Analytical Chemist., AOAC.INC. Arlington, Virgina. USA. Pp.1298.

AZARDO (2009). Arsi Zone Agricultural and Rural Development Official annual report.

Awet Estifanos (2007). Feed utilization, body weight change and Carcass characteristics of intact and castrated afar sheep fed urea treated tef straw and supplemented with graded levels of wteat bran.An MSc Thesis presented to School of Graduate Studies of Haramaya University. 45p. 


\section{Abebe Gemechu and Yoseph Mekasha}

Awet Estifanos and Solomon Melaku (2009). Supplementation of graded level of wheat bran to intact and castrated Afar sheep fed on urea treated teff straw: Effects on feed intake, digestibility, and body weight and carcass parameters. East Africa Journal of Science 3(1): 28-40.

Birhanu Mamo (2010). Effect of supplementation of malty barley by-products, wheat bran and their mixtures on feed intake, digestibility, body weight change and Carcass parameters in field pea haulms based feeding of Arsi-Bale sheep. MSc Thesis presented to school of graduate studies of Haramaya University.

CSA (Centeral Stastical Authority), (2004). The 2001/2002 Ethiopian Agricultural Sample Enumeration (EASE), Executive Summarry, Addis Ababa.

Emebet Legesse (2008). Supplementation of blackhead Ogaden sheep fed haricot bean haulms with mixture of wheat bran and berwer dried grain: Effect on feed utilization, live weight gain and carcass parameters. An MSc Thesis presented to School of Graduate Studies of Haramaya University.pp.46.

Ermias Tekletsadik (2008). The effect of supplementation with barley bran, linseed meal and their mixture on performance of Arsi-Bale sheep fed basal diet of faba bean haulms. An MSc Thesis presented to School of Graduate Studies of Haramaya University. pp.24-25

FAO (Food and Agriculture Organization of the United Nations), (2002). Animal production based on crop residues; China's experiences. FAO Animal Production and Health Paper. No. 149. 39p.

Gatenby, R.M. (2002). Sheep. The tropical agriculturalist, Macmillan, Oxford, UK. pp 3-144.

Getahun Kebede (2006). Effect of urea treatment and leucaena supplementation on the utilization of wheat straw by sheep. An MSc Thesis presented to School of Graduate Studies of Haramaya University.
Sci. Technol. Arts Res. J., Oct-Dec 2015, 4(4): 01-08

Hirut Yirga (2008). Supplementation of Concentrate mix to hararghe highland sheep fed on urea treated maize Stover: effect on feed utilization, live weight change and carcass characteristics. An MSc Thesis presented to School of Graduate Studies of Haramaya University. pp. 40-46

KARC (kulumsa Agricultural Research Center), (2009). Annual reports of kulumsa agricultural Research center. Assela, Ethiopia. 6p.

Markos Tibbo, Jan Philipson and Worknesh Ayelew (2006). Sustainable sheep breeds in the central Ethiopia Highlands. A Doctorial Thesis Presented to Swedish University of Agricultural Science. Uppsala.11.

McDonald. P., Edward, R.A., halgh, J.G.and Morgan, C.A. (2002). Animal Nutrition $6^{\text {th }}$ edision.pp635-661.

Melase Gashu (2008). Effect of supplementation with Noug cake, wheat bran and their mixture on feed intake, digestibility and live weight changes of Washera Sheep fed urea treated finger millet straw. An MSc Thesis presented to School of Graduate studies of Haramaya University. Pp.8-9.

Rehrahie Mesfin and Ledin, I. (2004). Assessment of treatment and urea of treatment straw for cattle feeding in Selale centeral Ethiopia. Ethiopia. Ethiopian Journal of Animal Production 4(1): 22-35.

SAS (2002). Statistical Analysis system, Version 9, Institute, Inc., Cary, NC, USA.

Tesfaye Hagos and Solomon Melaku (2009). Fed intake, digestibility, body weight change and carcass parameters of Afar rams fed tef (Eragrostis tef) straw supplemented with graded levels of concentrate mix. Tropical Journal of Animal Health Production 41: 599-606.

Van Soest, P.J. and Roberson, J.B. (1985). Analysis of forage and fibrous feed. A laboratory mannual, Cornell University, USA. 